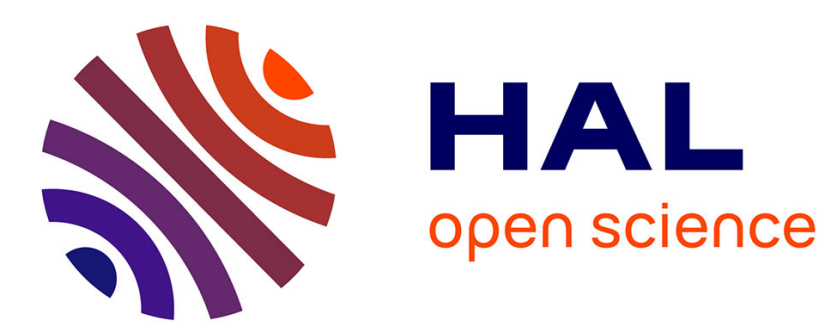

\title{
Cannibals in the forest: A comment on Defleur and Desclaux (2019)
}

Ludovic Slimak, Christopher Nicholson

\section{To cite this version:}

Ludovic Slimak, Christopher Nicholson. Cannibals in the forest: A comment on Defleur and Desclaux (2019). Journal of Archaeological Science, 2020, 117, pp.105034. 10.1016/j.jas.2019.105034 . halshs03002490

\section{HAL Id: halshs-03002490 \\ https://shs.hal.science/halshs-03002490}

Submitted on 29 Dec 2020

HAL is a multi-disciplinary open access archive for the deposit and dissemination of scientific research documents, whether they are published or not. The documents may come from teaching and research institutions in France or abroad, or from public or private research centers.
L'archive ouverte pluridisciplinaire HAL, est destinée au dépôt et à la diffusion de documents scientifiques de niveau recherche, publiés ou non, émanant des établissements d'enseignement et de recherche français ou étrangers, des laboratoires publics ou privés. 


\section{Cannibals in the forest: A comment on Defleur and Desclaux (2019)}

Ludovic Slimak $^{\mathrm{a}, * *}$ slimak@univ-tlse2.fr, Christopher Nicholson ${ }^{\mathrm{b}, *}$ Christopher.M.Nicholson@asu.edu

${ }^{a}$ CNRS UMR 5608 TRACES, Université Toulouse Jean Jaurès, Maison de la Recherche, 31058, Toulouse

Cedex 9, France

${ }^{\mathbf{b}}$ Center for Digital Antiquity, School of Human Evolution and Social Change, Arizona State University, PO 872402, Tempe, AZ, 85287, USA

*Corresponding author.

** Corresponding author.

\section{Abstract}

Though rare in the archaeological record, cannibalism has been documented among many different hominin populations; however, the mechanisms driving such behaviors remains poorly understood. Recent research that evaluates the hypothesized Neanderthal nutritional cannibalism at the Middle Palaeolithic cave site of Baume Moula-Guercy (BMG) in Mediterranean France, is one case that, in our opinion, is not fully substantiated by the evidence put forth by Defleur and Desclaux (2019). Using site occurrence data from the Last Interglacial (MIS 5e), the biogeography of extinct reptile species, and cut mark taphonomic evidence, Defleur and Desclaux (2019) suggest that the Neanderthal remains found in Layer XV of the cave are the result of nutritional cannibalism. The authors argue that a regional collapse of Neanderthal populations was the result of a depletion of prey biomass, caused by a profound upheaval of local environmental conditions, thus causing the Neanderthals at BMG to resort to cannibalism. In this response paper, we attempt to show that the methods and materials used by Defleur and Desclaux 1) do not reflect the known number of Eemian-aged sites, 2) do not present sufficient evidence related to the environmental stress conditions at BMG that would warrant cannibalism, and 3) taphonomic evidence on Neanderthal remains does not strictly support the argument for nutritional cannibalism. Additional study of the $\mathrm{BMG}$ remains is necessary before ruling out other processes related to the post-mortem treatment of the Neanderthal corpses.

Keywords: Cannibalism; Neanderthals; Eemian; Eurasia; France 


\section{Introduction}

The topic of cannibalism in prehistory is the subject of much controversy (Chaline, 1972; Gibbons, 1997; Hurlbut, 2000; Marlar et al., 2000; Saladié and Rodríguez-Hidalgo, 2017; Stoneking, 2003; Villa, 1992; White, 2001, Yustos and de los Terreros, 2015), thus the physical evidence and methods used to justify such a conclusion at a site must be robust, and replicable. Because of the delicate nature of the topic, this response paper addresses several issues that we have identified with the Defleur and Desclaux (2019) hypothesis of nutritional cannibalism at the Middle Palaeolithic site of Baume Moula-Guercy, France (BMG). The onus of distinguishing cannibalism, whether done for nutritional purposes or resulting from alternative behaviors, requires substantial evidence related to the differential treatment of Homo remains from other species, a precise understanding of the depositional context of the remains, and evidence that the remains were not deposited as the result of some culturally specific mortuary practices (Villa, 1992). Based on the requisite evidence to support such straightforward conclusions, we propose that Defleur and Desclaux (2019) do not meet these criteria and we discuss why the BMG data may be indicative of other complex behaviors.

A central tenant of Defleur and Desclaux (2019) focuses on the notion that there was wide spread population collapse in western Eurasia during the Last Interglacial, with only a few regions of the European continent able to maintain sufficient populations. Their hypothesis is, in part, based on the assumption that "(t)he distribution of Eemian Interglacial-aged sites is sporadic throughout Western Europe" noting that localities from northern Germany "form a fairly dense group, in contrast to the general scarcity of Eemian sites in the rest of Western Europe" (2019:114). Furthermore, because of a paucity of sites, the authors propose "that the Neanderthal cannibalism evident at BMG cave Layer $\mathrm{XV}$ is a nutritional cannibalism that emerged in response to the profound upheaval of their previously enduring environmental conditions" (2019:115) and "paleoanthropological sites of Eemian age are extremely rare due to a drastic decline in the European human population during this period" (2019:115). Though we agree that there are fewer Eemian-aged sites in western Eurasia than in later periods, the collection of sites that Defleur and Desclaux present, in our opinion, do not reflect all of the sites with a known MIS 5e component, thus leading to erroneous conclusions related to different population dynamics. Here, we attempt to show that the methods and materials used by Defleur and Desclaux 1) do not accurately reflect the number of known sites on the landscape during the MIS 5e Last Interglacial, 2) do not present sufficient evidence related to the environmental conditions at BMG that indicate "stress" conditions that would warrant cannibalism, and 3) their taphonomic evidence of the Neanderthal remains does not strictly support the argument for nutritional cannibalism or even cannibalism sensu lato at BMG.

\section{Eemian-aged sites and components}

Generally, and for a variety of taphonomic reasons, sites from older periods are less well-preserved than those that are more recent, and the Eemian record in western Eurasia is no exception. However, sites with a MIS 5e component are more ubiquitous than those cited by Defleur and Desclaux. In their narrative, Defleur and Desclaux identify only 10 sites in western Eurasia (Gröbern, Rabütz, Grabschütz, Taubach, Neumark Nord and Lehringen, Caours, Krapina, Bolomor Cave and BMG) as having stratigraphic layers dating to MIS 5e. Regarding BMG, the authors note that "only layer XV of BMG is confidently and unambiguously attributed to 
MIS 5e" in Southern France" (2019:119). The authors contend that Neanderthals had likely abandoned most parts of Europe because of a lack of natural resources when compared to the previous and subsequent periods, and because low population density groups were of insufficient size to allow for adequate human reproduction. With the exception of Saccopastore, in Italy, the authors do not provide evidence as to why only 10 sites are used in their analysis, when numerous studies have documented far more sites (Chabai et al., 2005, Gaudzinski-Windheuser and Roebroeks, 2011, Nicholson, 2017, Richter, 2005, Richter, 2008, Richter, 2016, Speelers, 2000, Wenzel, 1998, Wenzel, 2007). Instead of 10 sites in the region, an overview of the literature shows that there are approximately 85 sites with a cultural layer attributable to the Eemian (Table 1 and Fig. 1 ). Based on this increased number of sites, it is possible to glean a sense of the distribution of Neanderthal populations throughout western Eurasia and how these populations were able to adapt to numerous climatic zones, showing a preference for warm temperate and mesic climates (Nicholson, 2017). As radiometric dating improves, it is possible that subsequent research could disprove the presence of an Eemian component at some of these sites. It is even possible such future evidence could demonstrate that only 10 sites "unambiguously" date to MIS 5e, however, excluding 75 other sites with no discussion, prompts questions regarding the hypothesis and methods of the authors aforementioned. Furthermore, their attribution of BMG Layers XIV-XV as dating to MIS $5 \mathrm{e}$ is not itself exempt of serious questions.

alt-text: Table 1

Table 1

Site names, countries, Eemian layer, and references for 85 MIS 5e sites.

\begin{tabular}{|c|c|c|c|}
\hline Site & Country & Eemian Layer & Reference \\
\hline Ailly sur Noye & France & Unspecified & Locht et al. (2016) \\
\hline Ambrona & Spain & Layer AS1 & $\begin{array}{l}\text { (Howell et al., 1991; Markova and Puzachenko, 2018; Villa et al., } \\
\text { 2001) }\end{array}$ \\
\hline Arenero de Arriaga & Spain & Layer 1.1 & Markova and Puzachenko (2018) \\
\hline Arlampe & Spain & Level D & Rios-Garaizar et al. (2013) \\
\hline Auteuil & France & Level 1 & Goval et al. (2016) \\
\hline Balzi Rossi/Menton & Italy & Unspecified & Wenzel (2007) \\
\hline Baume de Gigny & France & Levels XII-XV & (Richter, 2005; Slimak et al., 2010) \\
\hline Baume Flandin & France & Unspecified & Cregut-Bonnoure et al. (2010) \\
\hline Beharovce-Sobotisko & Slovakia & Unspecified & Wenzel (2007) \\
\hline Belokuzminovka & Ukraine & Unspecified & Richter (2005) \\
\hline
\end{tabular}




\begin{tabular}{|c|c|c|c|}
\hline Bisnik Cave & Poland & Level A3 & Cyrek et al. (2014) \\
\hline Bockstein & Germany & $\begin{array}{l}\text { BS III (Layers } \\
\text { h \& i) }\end{array}$ & $\underline{\text { https://www.nespos.org/display/PublicNesposSpace/Bockstein }}$ \\
\hline Bojnice III & Slovakia & Layer X and XI & Neruda (2012) \\
\hline Bolomor & Spain & Layer II & (Fernández Peris et al., 2012; Markova and Puzachenko, 2018) \\
\hline Burgtonna & Germany & Unspecified & Speelers $(2000)$ \\
\hline Can Costella & Spain & $\begin{array}{l}\text { Geological } \\
\text { horizon MA- } \\
\text { GR }\end{array}$ & https://www.nespos.org/display/PublicNesposSpace/Can+Costella \\
\hline Caours & France & Level 4 & (Antoine, 2012; Sier et al., 2015) \\
\hline Cova del Rinoceront & Spain & Layers IIIa,b & Markova and Puzachenko (2018) \\
\hline Cova Eiros & Spain & Layer 3 & (Álvarez et al., 2011; Grandal-d'Anglade, 1993) \\
\hline Crvena Stijena & Montenegro & $\begin{array}{l}\text { Layer XXIV } \\
\text { (XXIX-XVIII) }\end{array}$ & (Musil, 2010; Wenzel, 2007) \\
\hline Cueva del Angel & Spain & Layer I-XIII & Barroso Ruíz et al. (2011) \\
\hline $\begin{array}{l}\text { Cueva Negra del } \\
\text { Estrecho }\end{array}$ & Spain & Layer 15 & (Markova and Puzachenko, 2018; Walker et al., 1998) \\
\hline Ehringsdorf & Germany & Unspecified & (Richter, 2016; Weber et al., 1996) \\
\hline El Castillo & Spain & Layers $24-26$ & $\begin{array}{l}\text { (Richter, 2005); https://www.nespos.org/display/PublicNesposSpac } \\
\underline{\text { e/El+Castillo }}\end{array}$ \\
\hline Elaea & Greece & Unspecified & (Harvati et al., 2009; Richter, 2005) \\
\hline Elbeuf I & France & Level 4 & (Cliquet et al., 2009; Cliquet et al., 2003) \\
\hline Estret de Trago & Spain & Layer UA3 & $\underline{\text { https://www.nespos.org/pages/viewpage.action?pageId=29886295 }}$ \\
\hline Fontechevade & France & Level C & (Cheylan, 1981; McPherron et al., 2012) \\
\hline Ganovce & Slovakia & Layer 3 & (Richter, 2005; Wenzel, 2007) \\
\hline Gouberville & France & Unspecified & Speelers, 2000(Speelers, 2000) \\
\hline Grabschutz & Germany & Unspecified & $\begin{array}{l}\text { (Gaudzinski-Windheuser and Roebroeks, 2011; van Kolfschoten, } \\
\text { 2002) }\end{array}$ \\
\hline Grobern & Germany & Layer 4 & $\begin{array}{l}\text { (Gaudzinski-Windheuser and Roebroeks, 2011); https://www.nespo } \\
\underline{\text { s.org/pages/viewpage.action?pageId }=5701}\end{array}$ \\
\hline Grossoeuvre & France & Unspecified & (Cliquet et al., 2003; Locht et al., 2016) \\
\hline Grotte Mandrin & France & Layer I & (Slimak, unpublished) \\
\hline Hangenbieten I & Germany & Unspecified & (Bosinski, 1967; Richter, 2016) \\
\hline
\end{tabular}




\begin{tabular}{|c|c|c|c|}
\hline Horka-Ondrej & Slovakia & Unspecified & Wenzel (2007) \\
\hline Hranovnica-Hincava & Slovakia & Unspecified & Wenzel (2007) \\
\hline Ilskaya & Russia & Levels VI-VIII & Golovanova and Doronichev (2003) \\
\hline Kabazi & Ukraine & Unit V/VI & (Chabai et al., 2005; Richter, 2005) \\
\hline Karain Cave & Turkey & Unspecified & Richter (2005) \\
\hline Krapina & Croatia & $\begin{array}{l}\text { Layer } 8 \text { (Layer } \\
4 ?)\end{array}$ & $\begin{array}{l}\text { (Gaudzinski-Windheuser and Roebroeks, 2011); https://www.nespo } \\
\underline{\text { s.org/display/PublicNesposSpace/Krapina }}\end{array}$ \\
\hline Kulna Cave (Sloup) & $\begin{array}{l}\text { Czech } \\
\text { Republic }\end{array}$ & Layer 11-13a & (Musil, 2010; Richter, 2005) \\
\hline Lazaret & France & Level CIII & Valensi (2000) \\
\hline $\begin{array}{l}\text { Le Grand Abri aux } \\
\text { Puces }\end{array}$ & France & Level 2 & Slimak et al. (2010) \\
\hline Lehringen & Germany & Layer IV & $\begin{array}{l}\text { (Gaudzinski-Windheuser and Roebroeks, 2011); https://www.nespo } \\
\text { s.org/display/PublicNesposSpace/Lehringen }\end{array}$ \\
\hline Lezetxiki & Spain & Level $\mathrm{Vb}$ & (Arriolabengoa et al., 2018; Falgueres et al., 2005) \\
\hline $\begin{array}{l}\text { Montfarville - Anse de } \\
\text { Quéry }\end{array}$ & France & Unspecified & (Coutard and Cliquet, 2005; Locht et al., 2016) \\
\hline Moravský Krumlov IV & Slovakia & Layer 2 & Neruda and Nerudová (2010) \\
\hline Moula-Guercy & France & Layer XIV-XV & Valensi et al. (2012) \\
\hline Neumark-Nord & Germany & Layer 2 & $\begin{array}{l}\text { (Gaudzinski-Windheuser and Roebroeks, 2011) https://www.nespos. } \\
\text { org/display/PublicNesposSpace/Neumark }\end{array}$ \\
\hline Payre & France & Layer D & Rivals et al. (2009) \\
\hline Phoben & Germany & Unspecified & Wenzel (2007) \\
\hline Port-Racine & France & Unspecified & Wenzel (2007) \\
\hline Predmostf I-III & $\begin{array}{l}\text { Czech } \\
\text { Republic }\end{array}$ & Unspecified & https://www.nespos.org/pages/viewpage.action?pageId=65404992 \\
\hline Rabutz & Germany & Unspecified & $\begin{array}{l}\text { (Gaudzinski-Windheuser and Roebroeks, 2011; van Kolfschoten, } \\
\text { 2002) }\end{array}$ \\
\hline Ramandils & France & Level IV & Moles and Boutié (2009) \\
\hline Rheindahlen & Germany & Layer B & https://www.nespos.org/display/PublicNesposSpace/Rheindahlen \\
\hline Rochelot & France & Niveau d1 & https://www.nespos.org/display/PublicNesposSpace/Rochelot \\
\hline Roisel & France & Unspecified & (Gautier, 1989; Swinnen et al., 1996) \\
\hline Saccopastore & Italy & Layer $2 \mathrm{a}$ & https://www.nespos.org/display/PublicNesposSpace/Saccopastore \\
\hline
\end{tabular}




\begin{tabular}{|c|c|c|c|}
\hline $\begin{array}{l}\text { Saint-Germain-des- } \\
\text { Vaux }\end{array}$ & France & $\mathrm{D} 2 \mathrm{~A}$ & Bocquet-Appel and Tuffreau (2009) \\
\hline Saint-Vaas-la-Hougue & France & Unspecified & Speelers $(2000)$ \\
\hline Sclayn & Belgium & Layer 4 & $\begin{array}{l}\text { (Gaudzinski-Windheuser and Roebroeks, 2011); https://www.nespo } \\
\text { s.org/display/PublicNesposSpace/Scladina }\end{array}$ \\
\hline Seclin & France & Unspecified & (Conard, 1990; Tuffreau et al., 1985) \\
\hline Seelberg & Germany & Unspecified & Speelers (2000) \\
\hline $\begin{array}{l}\text { Sesselfelsgrotte, Untere } \\
\text { Schichten }\end{array}$ & Germany & Unspecified & (Richter, 2016; Weißmüller, 1995) \\
\hline St. Marcel & France & Level U & (Cregut-Bonnoure et al., 2010; Slimak et al., 2010; Wenzel, 2007) \\
\hline Stajnia Cave & Poland & D1 Layer & $\begin{array}{l}\text { http://www.fossilized.org/Human_paleontology/_sites_expanded.ph } \\
\text { p?locality=Stajnia\%20Cave\&primy_key }=1037\end{array}$ \\
\hline Steinmühle & Germany & Unspecified & Wenzel (2007) \\
\hline Stuttgart-Bad Cannstatt & Germany & Unspecified & (Richter, 2016; Wenzel, 1998) \\
\hline $\begin{array}{l}\text { Stuttgart- } \\
\text { Unterturkheim }\end{array}$ & Germany & Unspecified & (Gaudzinski-Windheuser and Roebroeks, 2011) \\
\hline Taubach & Germany & Level XI & $\begin{array}{l}\text { (Gaudzinski-Windheuser and Roebroeks, 2011); https://www.nespo } \\
\text { s.org/display/PublicNesposSpace/Taubach }\end{array}$ \\
\hline Theopetra & Greece & Level II & Facorellis et al. (2013) \\
\hline Treauville & France & Unspecified & Speelers (2000) \\
\hline Vaufrey & France & Layers II-IV & Hernandez et al. (2014) \\
\hline Veldwezelt-Hezerwater & Belgium & Layer B1 & Vanmonfort et al. (1998) \\
\hline Veltheim & Germany & Unspecified & Speelers (2000) \\
\hline Veternica Cave & Croatia & Layer J & (Musil, 2010; Wenzel, 2007) \\
\hline Vindija Cave & Croatia & Layer G3 & https://www.nespos.org/display/PublicNesposSpace/Vindija \\
\hline $\begin{array}{l}\text { Vogelherd, } \\
\text { Hohlensohle }\end{array}$ & Germany & Unspecified & (Richter, 2016; Wenzel, 1998) \\
\hline Wallertheim & Germany & Wal A \& B & Adler et al. (2003) \\
\hline Waziers & France & Unspecified & (Locht et al., 2016; Verleijsdonk, 2018) \\
\hline Weimar-Parktravertin & Germany & $\begin{array}{l}\text { Lower } \\
\text { Travertine }\end{array}$ & $\begin{array}{l}\text { (Gaudzinski-Windheuser and Roebroeks, 2011); https://www.nespo } \\
\underline{\text { s.org/display/PublicNesposSpace/Weimar }}\end{array}$ \\
\hline Yezupil & Ukraine & Level III & (Eanczont et al., 2009; Richter, 2005) \\
\hline
\end{tabular}




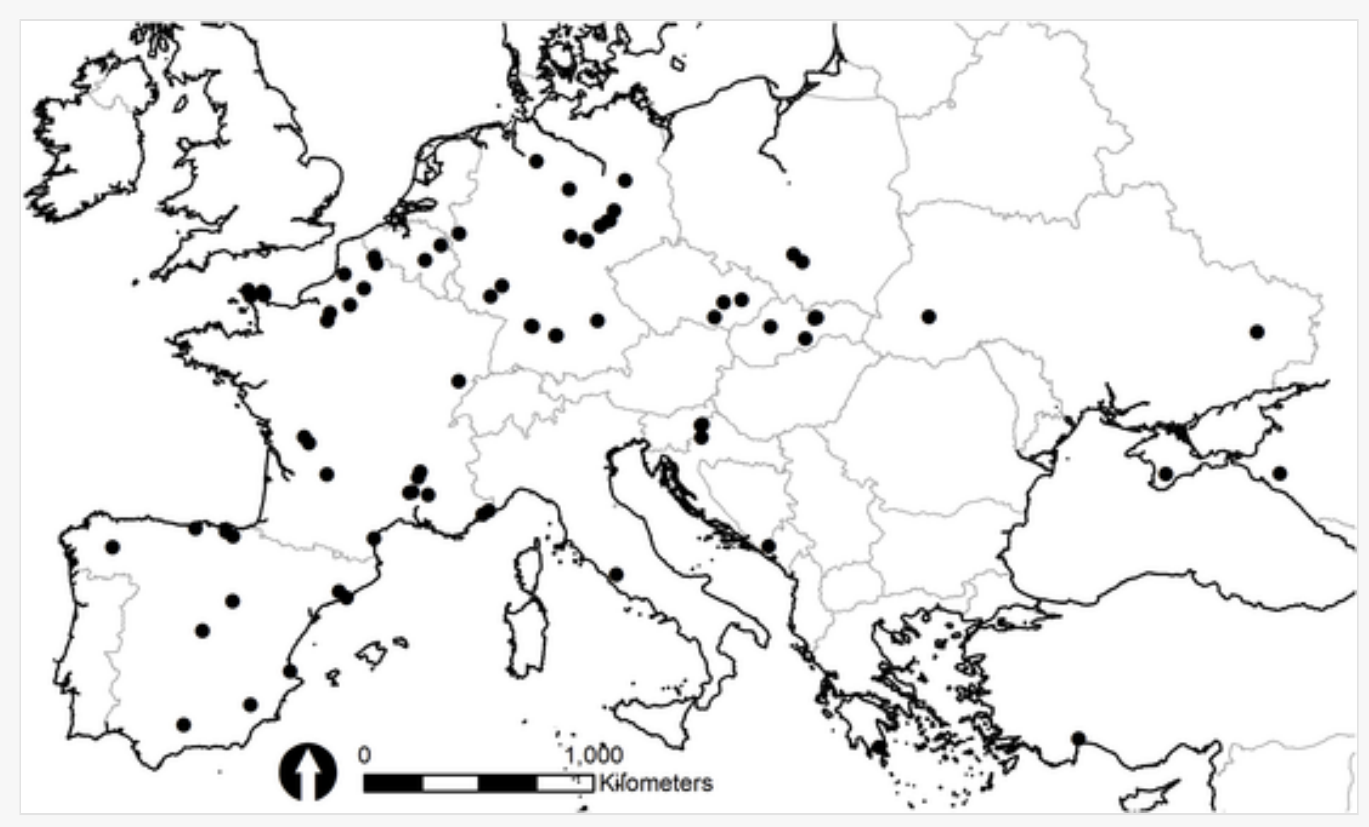

Location of 85 sites with a component dating to MIS 5e (see Table 1 for site names and references).

The biostratigraphic context at BMG is indeed indicative of a warm climate, signifying that Layers XIV-XV are from a warm phase of the Last Interglacial. Radiometric dating should help to clarify the classified MIS 5e layers at BMG; unfortunately, the obtained measures do not directly support a MIS 5e attribution for Layers $\mathrm{XIV}-\mathrm{XV}$. In terms of the radiometric dates collected from the site, these layers could be correlated with one of the other warm sub-stages (e.g., 5a or 5c) rather than the warmer 5e stage. Only one radiometric measure with a reported date is consistent with having an Eemian designation in Layer XV. Defleur and Desclaux note that "(r)ecent U-series and ESR dating provided a minimum date of $119 \pm 13 \mathrm{ky}$ for Layer XV. The probable age range is approximately 120-130 ky" (Willmes et al., 2016) (Defleur and Desclaux, 2019:118). However, the chronology of layers XIV to XV has been documented as being jumbled, making their chronological position unclear.

In another recent study of BMG, Wilmes et al. (2016:318) note that "the CSUS/ESR ages for Layer XIV $(n=2)$ are not conclusive, with one age estimate at $70 \pm 4 \mathrm{ka}$ and another at $97 \pm 6 \mathrm{ka}$. The younger age estimate for Layer XIV does not agree with the stratigraphy and biostratigraphy of the site, and more direct dating of material from this layer is needed to resolve this discrepancy". These dates do not effectively match with the BMG XIV attribution to MIS 5e but could be congruent with one of the most recent warm sub-stages from MIS 5. Regarding Layer XV, Willmes et al. (2016:318) demonstrate that "the age estimates of the Neanderthal fossil bearing Layer XV are based on 3 faunal teeth $(3039,3041,3042)$, yielding consistent ESR age estimates ranging between $97 \pm 10 \mathrm{ka}$ and $119 \pm 13 \mathrm{ka}$. The large sigma values assigned to these dates indicates that the layer could encompass both MIS 5e and MIS 5c. An assignment of the layer to MIS 5c could explain the presence of species that prefer continental and cooler conditions (infra) versus the warmer temperatures at the peak of MIS 5e. This alternative attribution of layers would also be congruent with 
additional BMG U-series dates of two Neanderthal teeth from Layer XV that "agree with an age for Layer XV corresponding to at least MIS 5 sensu lato" (Willmes et al., 2016:318). The precise determination of Layers $\mathrm{XIV}-\mathrm{XV}$, especially in terms of chronological position and assignment strictly to MIS 5e require further testing and more precise radiometric dating.

Whatever the true chronological position of BMG XIV-XV Defleur and Desclaux conclude, based on 10 selected sites, that their "inventory of Mousterian sites attributed to MIS 5e in the southern half of France and elsewhere in Europe shows a collapse of the human population during the Eemian period of global warming" ( Defleur and Desclaux, 2019:122). However, this assumption is not based on a summed probability distribution model of population nor any spatial analysis of the distribution of the Mousterian sites in region. Rather it is built on a visual comparison of the distribution of select sites dating to MIS 6 and MIS 4/3 sites. Their Figure 5 presents a non-exhaustive list of prehistoric sites (mostly stratified cave sites) from MIS 6 thru MIS 3 in southern France, which collectively plots $\sim 92$ sites, though no database or list of sites is provided; therefore none of these maps are reproducible. These maps attempt to compare the spatial distribution of Neanderthal populations that have very different durations on the landscape, with $\sim 15 \mathrm{ky}$ assigned to MIS $5 \mathrm{e}, \sim 70 \mathrm{ky}$ to MIS6, and $\sim 50 \mathrm{ky}$ covering MIS4/3. These spatial and temporal scales are not easily comparable without some statistical manipulation of the data, though none of the data are presented.

In southern France, we identify $\sim 10$ sites with a cultural component dating to MIS 5e (Table 1 and Fig. 2). However, we are unable to perform a statistical comparison of Defleur and Desclaux's site data to ours. Proportionally there appear to be more than twice as many MIS 5e sites compared to their attribution of MIS6 sites. Based on this rudimentary comparison, one could conclude that the warmer Eemian period was particularly favorable to the expansion of Neanderthal populations across the region, with a rapidly growing population and expansion in the previously abandoned latitudes of northern Germany.

alt-text: Fig. 2

\section{Fig. 2}




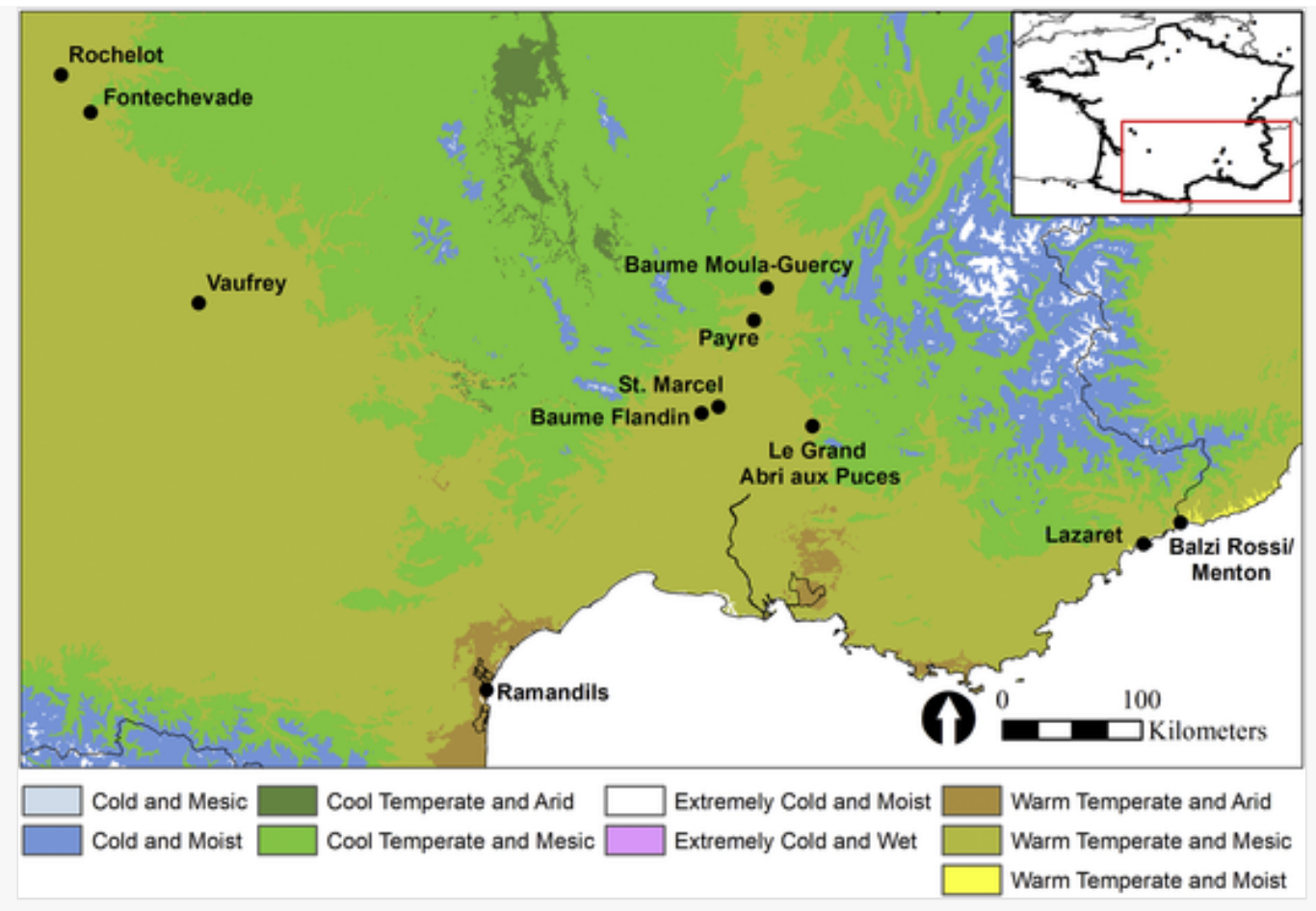

Map of southern France with MIS 5e sites and Eemian paleoclimate zones.

This anecdotal example is not robust, but could be tested using spatial analyses with a more exhaustive list of sites dating to MIS6 through 5 (or even 3). However, since the authors do not provide site dates, nor do they include climate/environmental data associated with these periods, their correlation between a warming climate and population collapse is not supported. Upon closer inspection, the data in fact may well support quite an opposite conclusion, with an expansion of the Neanderthal populations over the previous cold MIS6 phase.

\section{Climate and biogeography}

The MIS 5 climatic period spans roughly 50,000 years, whereas MIS 5e is far shorter spanning approximately 15,000 years. Defleur and Desclaux state that MIS 5e is warmer than the peak of the Holocene, therefore these temperatures serve as a diagnostic value when evaluating the presence of three species of extinct reptile identified in BMG Layer XV (Testudo hermanni, Malpolon monspessulanus, and Rhinechis scalaris). These reptiles are believed to prefer Mediterranean climates and are no longer found in the BMG area of the Soyons region. The authors note that the presence of these species indicates that the climate around the cave during the MIS 5e period was warmer and drier than at present, with the Mediterranean climate extending further north than the present day, following the Rhône Valley. The authors also note that Layer XIV contains the remains of Testudo hermanni, suggesting a relative stability of climatic conditions in the area throughout the duration of the Eemian and that the northern-most range of the Hermann tortoise is more than $100 \mathrm{~km}$ south of BMG.

The distribution of extinct species in a region may be correlated with the current or past distributions of a species, but the authors provide no evidence of this. Current environmental conditions in the Middle Rhône Valley are affected by a high degree of anthropogenic modification and are directly impacted by human activities related to deforestation, conversion of landscapes to pastures, and fire suppression; these 
anthropogenic processes have been at play since the beginning of the Holocene (Delhon et al., 2010) and could have impacted the distribution of these species. The past distribution of these reptiles in the more northern regions of their known Holocene distribution does not represent a direct proxy for a warmer phase for BMG XIV-XV, and the adaptive capabilities of the species to different and no-analog environments across the Holocene remains largely unknown. Additionally, the actual distribution of Malpolon monspessulanus does encompass slightly more northerly latitudes than BMG (Pottier et al., 2006). Focusing on Pleistocene data, Rhinechis scalaris remains have been recovered from a Middle Pleistocene sequence at the L'Igue des Rameaux site in the Tarn-et-Garonne area of France, far from Mediterranean climates and in a much more cool temperate Atlantic climatic context (Jeannet and Mein, 2016). Rhinechis scalaris is itself documented throughout the different climatic phases of the BMG sequence including Layers XIX, XVII, XVI attributed to the cold MIS6 phase, along with remains found in Layer VIII, in cold MIS4 conditions (Manzano, 2015).

A Pleistocene Atlantic distribution for Testudo hermanni is also documented at the site of Aven de la Fage, in Corrèze (Mourer et al., 1975) and in Fontéchevade in Charente (Cheylan, 1981; Hervet, 2000), both of which are located north of BMG and in a cooler Atlantic climate context. The Pleistocene distribution of these reptiles is not straight forward or indicative of a more Mediterranean climate, rather it corresponds to the phenotypic plasticity of these species to adapt to climates not directly comparable with their actual distribution (Geniez and Cheylan, 2012).

BMG XV also contains the remains of Triturus cristatus, Rana temporaria and Pelobates fuscus, which have a distribution indicative of continental and colder conditions (Manzano, 2015). The presence of these microfauna, which can inhabit no-analog cold and/or warm climates could indicate that the Middle Rhône Valley served as a natural north-south corridor recording Mediterranean influences well into southern France ( Manzano, 2015). It may be the case that the reptile remains at BMG do not record the MIS 5e optimal warm period, rather one of the subsequent, and less warm, MIS 5 sub-stages. The lines denoting the approximate distribution over time of three thermophilous reptiles identified in level XV in Defleur and Desclaux's Figure 3 (2019) remain arbitrary and are not supported with any climatic or ecological data. Using gridded global climate model data, Nicholson (2017) recreated paleoclimate zones of western Eurasia which shows that BMG was located in a Warm Temperate and Mesic climate during MIS 5e as mentioned by Defleur and Desclaux ( Fig. 2). However, Defleur and Desclaux's hand-drawn approximation of the geographic extent of the three extinct species is not based on any quantitative biogeographical analysis that attempts to accurately delineate where those warmer climate zones may have been located.

The question of the persistence of MIS6-adapted mammals and micromammals in Layers XIV-XV is particularly interesting, however their presence should not be used as a demonstration or definitive proof of a MIS 5e age for these layers, as the precise timing of these species' extinction is also unknown. The presence of P. lenki, A. bursae and M. brecciensis in Layers XIVa to XV is cited by Defleur and Desclaux as "not previously found in association in any late Pleistocene layers in Western Europe" (2019:116), however their distribution is known to exist at several localities post MIS 5, including more recent phases of the Upper Pleistocene (Chaline, 1970; Chaline, 1972; Defleur et al., 2001; Marquet, 1989). The presence of these species itself does not lead to an unambiguous and confident conclusion supporting a MIS 5e attribution of these layers. 


\section{Cannibalism}

The debate over the evidence and meaning behind Neanderthal cannibalism has gone on for more than 150 years. In 1871, Carl Vogt argued that far from being a mark of savagery, one could infer that anthropophagy was commonly considered a sign of some degree of civilization (Vogt, 1871)[Instruction: To DC: link reference]. The Baron de Lubac in 1873 noted that the evidence of Neanderthal cannibalism from the Grotte de Néron (a Mousterian cave site located less than $30 \mathrm{~m}$ from BMG) (Slimak, 2004) was likely "only by chance, and strange as this assertion may seem, the 'Cave Peoples' would not have been civilized enough to be cannibals" (de Lubac, 1873)[Instruction: To DC: link reference]. The same may be true today, in that we still do not have a good understanding behind all of the behavioral mechanisms related to prehistoric cannibalism.

To begin, Defleur and Desclaux make a case for nutritional stress based on the presence of linear enamel hypoplasia (LEH) on teeth. The presence of LEH's, however, appear to be common throughout Neanderthal and AMH hunter-gatherer populations (Guatelli-Steinberg et al., 2014) and does not present definitive evidence of nutritional stress related to cannibalism.

Regarding the taphonomic evidence for cannibalism at BMG, Defleur and Desclaux note that there is a higher percentage of cut marks on Neanderthal remains ( $50 \%)$ compared to those on red deer (Cervus elaphus) remains $(\sim 26 \%)$ implying that the Neanderthals occupying these layers were especially careful when cutting up the Neanderthal corpses (Defleur et al., 1999; Valensi et al., 2012). These differences in the percent of cut marks between Neanderthal and red deer bones is remarkable as the remains from these two species were found in direct spatial association (Defleur et al., 1999). These differences could be interpreted in two divergent ways. If the activities in BMG Layer XV represent a nutritional cannibalism event, then the high prevalence of cut marks on Neanderthal remains may well be supported by Defleur and Desclaux's hypothesis, as it would reflect the need to exploit all available protein from the Neanderthal corpses, as well as all other procured fauna. However, "low utility" Neanderthal bones, such as metapodials, phalanges, clavicle, and mandible, record a high number of cut marks ( 45\%), fitting with the Burger et al. (2005) prey as patch model of bad nutritional times, while only $17 \%$ of the corresponding red deer remains exhibit similar cut mark frequencies, an indication that the group was not under nutritional stress. It is very possible that the Neanderthal and red deer remains were not defleshed during the same occupational event, as red deer remains were clearly not over processed.

The Neanderthal and red deer remains seem to have been processed in a specific manner and do not share a quantitative equivalence with other faunal remains. The "over-treatment" of Neanderthal remains is not documented elsewhere in Layer XV. Other artiodactyl and perissodactyl remains from the same layer are less abundant (but of comparable size with 97 remains, compared to 193 for C. elaphus and 120 Neanderthal remains). This diverse faunal assemblage includes the remains from at least 12 other species of medium- and large-size ungulates (Capra, Capreolus, Rangifer, Equus, Megaloceros giganteus, and Bos) that do not record comparable cut marks.

In a separate analysis of the faunal assemblage at BMG, Valensi et al. (2012) state that the high percentage of cut marks on Neanderthal remains indicates that great care was taken in cutting up the corpses; whereas Defleur and Desclaux suggest the opposite, that the high frequency of cut marks points to an "exacerbated 
need for protein". The fact that the associated ungulates were not treated as intensively, or carefully, as the Neanderthal corpses should be further explored. This pattern suggests that there could have been several occupational phases comprising Layer XV. There were likely short temporal differences between occupational phases when Neanderthals would have butchered ungulates for food and when the Neanderthal bodies were defleshed and disarticulated.

If Layer XV does reflect several hominin occupations then the scarcity of lithics also needs to be explained, as they do not support repeated occupations at the site. There are remarkably few lithic remains from Layer XV, totaling 227 lithic artifacts $(>2.5 \mathrm{~cm})$ which includes a limited number of retouched tools $(\mathrm{n}=57)$ (Defleur, 2015). This lithic assemblage represents less than one tool for every two Neanderthal remains, or one tool for every 100 pieces of bone (from all species combined).

If the BMG Neanderthal corpses were defleshed and disarticulated for consumption then there should be distinct taphonomic signatures between the associated faunal and Neanderthal remains, though several lines of evidence to unravel these differences have gone unexplored. For instance, though Defleur et al., 's 1999 research shows images from a scan electron microscope (SEM), it does not appear that they investigate the micromorphology of the cut marks. A recent SEM analysis of cut marks on human remains at Gough's Cave site in the United Kingdom and the Lepenski Vir, Padina, and Vlasac sites in Serbia (Bello et al., 2016) attempt to determine the timing of cut marks based on their width, depth and opening angle of the cut mark and whether or not they were inflicted long after death. This type of analysis was also done by Garralda et al. (2005) to determine possible cannibalism practices at Combe-Grenal and Marillac (France). In this case, Garralda and colleagues propose that the cut marks were the result of "social/ritual" practices and not nutritional, and that there were potential funerary rituals that involved defleshing and dismemberment ( Garralda et al., 2005). This type of analysis does not appear to have been done with the BMG Neanderthal remains.

The possibility of dismemberment of corpses for secondary burial as described by Bello et al. (2016) should also be further explored. Bello and colleagues describe funerary practices that consist of the initial burial of dead bodies in the ground, followed by a period of decay, and finally the exhumation of remains and dismemberment for reburial or other ritual practices that have no relationship to caloric needs, a common case in ethnography. Because Defleur (2015) and Defleur et al. (1999) do not provide sufficient data and information for reanalysis, it is difficult to provide an alternative hypothesis other than the corpses may have been disarticulated for some ritualized purpose.

Finally, evaluating the nutritional content of different prey species has been one way of assessing the diet breadth of different human populations (Binford, 1978; Jones and Metcalfe, 1988; Lupo, 1998, 2006; Madrigal and Holt, 2002), and this line of evidence was recently explored by Cole (2017) who derived nutritional values for different hominins according to their body weight. Based on the caloric value of the six Neanderthal corpses at BMG (Cole, 2017), the amount of available calories to feed a Neanderthal group was low, especially given that of the six individuals only one is a large adult, one is a small adult, two are sub-adults, and two juveniles. The number of calories available would be nominal and would only feed a small Neanderthal population of 25 adult males for 1.13 days (Cole, 2017). 
If fauna and Neanderthal remains from Layer XV were utilized in the same phase of occupation, the discrepancy in their respective exploitation indicates that this cannibalism event was likely not a nutritional episode. The treatment of the Neanderthal bodies related to the extraction of all soft tissues, including appendicular skeletal elements, points to a distinct treatment of the Neanderthal remains versus the associated fauna, a proxy that could be indicative of more complex cannibalistic practices, including the potential for ritualized treatment of the bodies, though the exact practice remains unknown (Frayer et al., 2006; Saladié and Rodríguez-Hidalgo, 2017, Yustos and de los Terreros, 2015). Taphonomic evidence of dismemberment of a corpse does not necessarily correlate with cannibalism events. Rather than a nutritional act, the dismemberment of the Neanderthal bodies may well be indicative of complex and ritualized social behaviors or territorial behavior that remains to be precisely documented among this still misunderstood population ( Bahn, 1992; Carbonell et al., 2010; Conklin, 2001; Vilaca, 2000).

To some extent, Defleur and Desclaux neglect to discuss Neanderthal foraging during MIS 5e and the large body of literature that paints a different picture of food resources available to these populations. Richter (2016) clearly illustrates the relationship between Eemian Neanderthals hunting in forested regions with low-prey biomass versus hunting in open landscapes with high-prey biomass. Richter notes that even if encounter rates in forested areas with large-prey were low, because of a low Neanderthal population density, the impact of fewer prey items on the landscape should not affect human nutrition. Although herds of large-prey like mammoth, woolly rhino, reindeer and horse were not as abundant in forested areas, fauna such as Bos primigenius, Capreolous capreolus, Cervus elaphus, Dama dama, Equus ferus, and Sus scrofa (GaudzinskiWindheuser and Kindler, 2012; Gaudzinski-Windheuser and Roebroeks, 2011; Gaudzinski, 2004; Rivals et al., 2009) were well adapted to these environments, likely providing a sufficient source of protein for a small Human population. In addition to large-prey, more evidence is being uncovered regarding the importance of plants in Neanderthal diets' (El Zaatari et al., 2016; Wenzel, 1998; Wenzel, 2007) as well as other small fauna (Cochard et al., 2012; Morin et al., 2019). With population estimates in the region estimated as ranging between 1000 and 12,000 (Briggs et al., 2009; Dennell et al., 2011; Green et al., 2006; Sørensen, 2011) throughout Europe, it seems unlikely that the landscape could not nutritionally support such small groups.

\section{Conclusion}

The evidence for nutritional cannibalism at BMG put forth by Defleur and Desclaux, which includes an important lack of Eemian-aged sites in western Eurasia, a warmer climate for Layer XV as evidenced by extinct reptiles, and taphonomic evidence on Neanderthal and other faunal remains, does not support the hypothesis of the authors and is at best tentative. Here, we have attempted to demonstrate that there are several more Eemian-aged sites in western Eurasia than mentioned by the authors, with as many as 85 sites representing Neanderthal populations across the regions, counteracting their inclusion of a mere 10. We have also addressed the issue of biostratigraphy for Layer XV, noting that the presence of the three extinct reptile species does not lead to the conclusion that Layer XV is attributable to MIS 5e, especially given the other radiometric dating issues with the said layers at the site. Finally, while we do not question the presence of the cut mark evidence on Neanderthal remains, we do question Defleur and Desclaux's hypothesis that it represents a nutritional cannibalism event or even the result of cannibalistic practices sensu lato. Given that the frequency of cut marks on low utility elements is not equivalent between Neanderthal and faunal remains, 
the dismemberment of Neanderthal corpses may be the result of more complex cultural rites that archaeologists have yet to understand and/or document. Furthermore, given that the total Neanderthal population on the landscape was quite low, these widespread groups were thus likely to have been well adapted to hunting forested prey-species (as well as gathering and collecting), and with their overall feeble numbers, gaining access to adequate game to meet their caloric and nutritional needs, was not at all likely an issue. The evidence presented by Defleur and Desclaux, while interesting, is far from conclusive and unfortunately uses data that, in themselves, do not validate the authors hypothesis of Neanderthal cannibalism at BMG.

\section{Declaration of competing interest}

We, Ludovic Slimak and Christopher Nicholson, certify that all authors have seen and approved the final version of the manuscript being submitted. The article is the authors' original work, and hasn't received prior publication and isn't under consideration for publication elsewhere.

Furthermore, we declare that there is no financial/personal interest or belief that could affect our objectivity.

\section{Acknowledgements}

We would like to thank Rob Hope and Sally Starkey for their input and valuable suggestions.

\section{References}

The corrections made in this section will be reviewed and approved by journal production editor.

Adler, D., Prindiville, T., Conard, N.J., 2003. Patterns of spatial organization and land use during the Eemian interglacial in the Rhineland: new data for Wallertheim, Germany. Eurasian PreHistory 1, 2578.

Álvarez, X.R., de Lombera Hermida, A., Valcarce, R.F., Fernández, T.L., 2011. The Upper Pleistocene Site of Cova Eirós (Triacastela, Lugo, Galicia), to the West of Spanish Cantabria: the Palaeolithic Settlement of Galicia. British Archaeological Reports (BAR), Archaeopress Oxford, pp. 123-132.

Antoine, P., 2012. First evidence of Human occupation during the Eemian interglacial (MIS 5e) in Northern France at Caours (Somme Basin). Quat. Int. 279-280, 21.

Arriolabengoa, M., Iriarte, E., Aranburu, A., Yusta, I., Arnold, L.J., Demuro, M., Arrizabalaga, A., 2018. Reconstructing the sedimentary history of Lezetxiki II cave (Basque Country, northern Iberian Peninsula) using micromorphological analysis. Sediment. Geol. 372, 96-111.

Bahn, P., 1992. Cannibalism or Ritual Dismemberment. Cambridge encyclopedia of human evolution, $\mathrm{p}$. 330. 
Barroso Ruíz, C., Botella Ortega, D., Caparrós, M., Moigne, A.M., Celiberti, V., Testu, A., Barsky, D., Notter, O., Riquelme Cantal, J.A., Rodríguez, M.P., Carretero León, M.I., Monge Gómez, G., Khatib, S., Saos, T., Gregoire, S., Bailón, S., García Solano, J.A., Cabral Mesa, A.L., Djerrab, A., George Hedley, I., Abdessadok, S., Batalla Llasat, G., Astier, N., Bertin, L., Boulbes, N., Cauche, D., Filoux, A., Hanquet, C., Milizia, C., Moutoussamy, J., Rossoni, E., Verdú Bermejo, L., de Lumley, H., 2011. The Cueva del Angel (Lucena, Spain): an Acheulean hunters habitat in the South of the Iberian Peninsula. Quat. Int. 243, 105-126.

Bello, S.M., Wallduck, R., Dimitrijević, V., Živaljević, I., Stringer, C.B., 2016. Cannibalism versus funerary defleshing and disarticulation after a period of decay: comparisons of bone modifications from four prehistoric sites. Am. J. Phys. Anthropol. 161, 722-743.

Binford, L.R., 1978. Nunamiut: Ethnoarchaeology. Academic Press, New York.

Bocquet-Appel, J.-P., Tuffreau, A., 2009. Technological responses of Neanderthals to macroclimatic variations (240,000-40,000 BP). Hum. Biol. 81, 287-307.

Bosinski, G., 1967. Die mittelpaläolithischen Funde im westlichen Mitteleuropa, Böhlau.

Briggs, A.W., Good, J.M., Green, R.E., Krause, J., Maricic, T., Stenzel, U., Lalueza-Fox, C., Rudan, P., Brajković, D., Kućan, Ž., Gušić, I., Schmitz, R., Doronichev, V.B., Golovanova, L.V., de la Rasilla, M., Fortea, J., Rosas, A., Pääbo, S., 2009. Targeted retrieval and analysis of five neandertal mtDNA genomes. Science 325, 318-321.

Burger, O., Hamilton, M.J., Walker, R., 2005. The prey as patch model: optimal handling of resources with diminishing returns. J. Archaeol. Sci. 32, 1147-1158.

Carbonell, E., Cáceres, I., Lozano, M., Saladié, P., Rosell, J., Lorenzo, C., Vallverdú, J., Huguet, R., Canals, A., Bermúdez de Castro, J.M., 2010. Cultural cannibalism as a paleoeconomic system in the European lower Pleistocenethe case of level TD6 of gran dolina (sierra de Atapuerca, burgos, Spain). Curr. Anthropol. 51, 539-549.

Chabai, V., Richter, J., Uthmeier, T., 2005. In: Uthmeir, 2005. Kabazi II: Last Interglacial Occupation, Environment and Subsistence: Paleolithic Sites of Crimea, 1. (Simferopol, Cologne).

Chaline, J., 1970. Pliomys lenki, forme relique du Pléistocène supérieur de la grotte de Lezetxiki (Guipuzcoa, Espagne). Munibe 22, 43-49.

Chaline, J., 1972. Les rongeurs du Wurmien II de la grotte de 1'Hortus (Valflaunes, Herault). Etud. Quat. $1,233-240$.

Cheylan, M., 1981. Biologie et écologie de la tortue d'Hermann Testudo hermanni, Gmelin 1789: contribution de l'espèce à la connaissance des climats quaternaires de la France, Ecole pratique des hautes études. 
Cliquet, D., Mercier, N., Valladas, H., Froget, L., Michel, D., Vliet-Lanoë, B.V., Vilgrain, G., 2003. Apport de la thermoluminescence sur silex chauffes à la chronologie de site paléolithiques de Normandie: nouvelles données et interprétations [Thermoluminescence anting of burnt flints from Palaeolithic sites of Normandy recent advances]. Quaternaire, pp. 51-64.

Cliquet, D., Lautridou, J.-P., Antoine, P., Lamothe, M., Leroyer, M., Limondin-Lozouet, N., Mercier, N., 2009. La séquence loessique de Saint-Pierre-lès-Elbeuf (Normandie, France): nouvelles données archéologiques, géochronologiques et paléontologiques, Quaternaire. Revue de l'Association française pour l'étude du Quaternaire 20, 321-343.

Cochard, D., Brugal, J.-P., Morin, E., Meignen, L., 2012. Evidence of small fast game exploitation in the middle paleolithic of les canalettes aveyron, France. Quat. Int. 264, 32-51.

Cole, J., 2017. Assessing the calorific significance of episodes of human cannibalism in the Palaeolithic. Sci. Rep. 7, 44707.

Conard, N.J., 1990. Laminar lithic assemblages from the last interglacial complex in northwestern Europe. J. Anthropol. Res. 46, 243-262.

Conklin, B.A., 2001. Consuming Grief: Compassionate Cannibalism in an Amazonian Society. University of Texas Press.

Coutard, S., Cliquet, D., 2005. Chronostratigraphie des formations pléistocènes et peuplement paléolithique en contexte littoral : le Val de Saire (Normandie). Bull. Soc. Prehist. Fr. 477-499.

Cregut-Bonnoure, E., Boulbes, N., Daujeard, C., Fernandez, P., Valensi, P., 2010. New data on the large mammals fauna from the Eemian in the Southeast of France. Quaternaire 21, 227-248.

Cyrek, K., Sudoł, M., Czyżewski, Ł., Osipowicz, G., Grelowska, M., 2014. Middle palaeolithic cultural levels from middle and late Pleistocene sediments of biśnik cave, Poland. Quat. Int. 326-327, 20-63.

Defleur, A., 2015. Les industries lithiques moustériennes de la Baume moula-guercy (Soyons, ardèche). Fouilles 1993-1999. L'Anthropologie 119, 170-253.

Defleur, A., Desclaux, E., 2019. Impact of the last interglacial climate change on ecosystems and Neanderthals behavior at Baume Moula-Guercy, Ardèche, France. J. Archaeol. Sci. 104, 114-124.

Defleur, A., White, T., Valensi, P., Slimak, L., Crégut-Bonnoure, É., 1999. Neanderthal cannibalism at moula-guercy, Ardèche, France. Science 286, 128-131.

Defleur, A., Crégut-Bonnoure, É., Desclaux, E., Thinon, M., 2001. Présentation paléo-environnementale du remplissage de la Baume Moula-Guercy à Soyons (Ardèche): implications paléoclimatiques et chronologiques. L'Anthropologie 105, 369-408.

Delhon, C., Thiébault, S., Brochier, J.L., Berger, J.F., 2010. Dynamiques de végétation au Tardiglaciaire et à l'Holocène ancien en moyenne vallée du Rhône d'après les données anthracologiques, Quaternaire. 
Revue de l'Association française pour l'étude du Quaternaire 21, 281-293.

Dennell, R.W., Martinón-Torres, M., Bermúdez de Castro, J.M., 2011. Hominin variability, climatic instability and population demography in Middle Pleistocene Europe. Quat. Sci. Rev. 30, 1511-1524.

El Zaatari, S., Grine, F.E., Ungar, P.S., Hublin, J.-J., 2016. Neandertal versus modern human dietary responses to climatic fluctuations. PLoS One 11, e0153277.

Facorellis, Y., Karkanas, P., Higham, T., Brock, F., Ntinou, M., Kyparissi-Apostolika, N., 2013. Interpreting radiocarbon dates from the Paleolithic layers of Theopetra cave in Thessaly, Greece. Radiocarbon 55, 1432-1442.

Falgueres, C., Yokoyama, Y., Arrizabalaga, A., 2005. La Geocronología del yacimiento pleistocénico de Lezetxiki (Arrasate, País Vasco). Crítica de las dataciones existentes y algunas nuevas aportaciones, Munibe 57, 93-106.

Fernández Peris, J., González, V.B., Blasco, R., Cuartero, F., Fluck, H., Sañudo, P., Verdasco, C., 2012. The earliest evidence of hearths in southern Europe: the case of bolomor cave (valencia, Spain). Quat. Int. 247, 267-277.

Frayer, D.W., Orschiedt, J., Cook, J., Russell, M.D., Radovčić, J., 2006. Krapina 3: Cut Marks and Ritual Behavior?

Garralda, M., Giacobini, G., Vandermeersch, B., 2005. Nenderthal cutmarks: combe-grenal and marillac (France): a SEM analysis. Anthropologie 43, 189-198.

Gaudzinski, S., 2004. A matter of high resolution? The Eemian Interglacial (OIS 5e) in north-central Europe and Middle Palaeolithic subsistence. Int. J. Osteoarchaeol. 14, 201-211.

Gaudzinski-Windheuser, S., Kindler, L., 2012. Research perspectives for the study of Neandertal subsistence strategies based on the analysis of archaeozoological assemblages. Quat. Int. 247, 59-68.

Gaudzinski-Windheuser, S., Roebroeks, W., 2011. On Neanderthal subsistence in last interglacial forested environments in northern Europe. In: Conard, N.J., Richter, J. (Eds.), Neanderthal Lifeways, Subsistence and Technology: One Hundred Fifty Years of Neanderthal Study, Vertebrate Paleobiology and Paleoanthropology. Springer, New York, pp. 61-70.

Gautier, C., 1989. Technologie de l'industrie Mousterienne de Roisel (Somme), Paleolithique et Mesolithique du Nord de la France: nou velles recherches. Universite des Sciences et des Technologies de Lille Flandre-Artois, Lille, France, pp. 61-68.

Geniez, P., Cheylan, M., 2012. Les amphibiens et les reptiles du Languedoc-Roussillon et régions limitrophes: atlas biogéographique. Biotope.

Gibbons, A., 1997. Archaeologists rediscover cannibals. Science 277, 635-637. 
Golovanova, L.V., Doronichev, V.B., 2003. The middle paleolithic of the caucasus. J. World PreHistory $17,71-140$.

Goval, E., Hérisson, D., Locht, J.-L., Coudenneau, A., 2016. Levallois points and triangular flakes during the Middle Palaeolithic in northwestern Europe: considerations on the status of these pieces in the Neanderthal hunting toolkit in northern France. Quat. Int. 411, 216-232.

Grandal-d'Anglade, A., 1993. El Oso de las cavernas en Galicia, el yacimiento de Cova Eirós. Ser. Nova Terra 8, 1-285.

Green, R.E., Krause, J., Ptak, S.E., Briggs, A.W., Ronan, M.T., Simons, J.F., Du, L., Egholm, M., Rothberg, J.M., Paunovic, M., Pääbo, S., 2006. Analysis of one million base pairs of Neanderthal DNA. Nature 444, 330-336.

Guatelli-Steinberg, D., Stinespring-Harris, A., Reid, D.J., Larsen, C.S., Hutchinson, D.L., Smith, T.M., 2014. Chronology of linear enamel hypoplasia formation in the Krapina Neanderthals. PaleoAnthropology 431, 445.

Harvati, K., Panagopoulou, E., Runnels, C., 2009. The paleoanthropology of Greece. Evol. Anthropol.: Issues, News, Rev. 18, 131-143.

Hernandez, M., Mercier, N., Rigaud, J.-P., Texier, J.-P., Delpech, F., 2014. A revised chronology for the Grotte Vaufrey (Dordogne, France) based on TT-OSL dating of sedimentary quartz. J. Hum. Evol. 75, 53-63.

Hervet, S., 2000. Tortues du Quaternaire de France: critères de détermination, répartitions chronologique et géographique. Mesogee 58, 3-47.

Howell, F.C., Butzer, K.W., Freeman, L.G., Klein, R.G., 1991. Observations on the Acheulean occupation site of Ambrona (Soria Province, Spain) with particular reference to recent investigations (1980-1983) and the lower occupation. In: MAINZ, Y.-G.C.M. (Ed.), Zentralmusem, RomischGermanisches, Mainz, Germany.

Hurlbut, S.A., 2000. The taphonomy of cannibalism: a review of anthropogenic bone modification in the American Southwest. Int. J. Osteoarchaeol. 10, 4-26.

Jeannet, M., Mein, P., 2016. Les Muridae (Mammalia, Rodentia) du Pléistocène moyen de l'Igue des Rameaux (Tarn-et-Garonne, France), PALEO. Revue d'archéologie préhistorique 177-205.

Jones, K.T., Metcalfe, D., 1988. Bare bones archaeology: bone marrow indices and efficiency. J. Archaeol. Sci. 15, 415-423.

Locht, J.-L., Hérisson, D., Goval, E., Cliquet, D., Huet, B., Coutard, S., Antoine, P., Feray, P., 2016. Timescales, space and culture during the Middle Palaeolithic in northwestern France. Quat. Int. 411 (A), $129-148$. 
Lupo, K.D., 1998. Experimentally derived extraction rates for marrow: implications for body Part Exploitation strategies of plio-pleistocene hominid scavengers. J. Archaeol. Sci. 25, 657-675.

Lupo, K.D., 2006. What explains the carcass field processing and transport decisions of contemporary hunter-gatherers? Measures of economic anatomy and zooarchaeological skeletal Part Representation. J. Archaeol. Method Theory 13, 19-66.

Madrigal, T.C., Holt, J.Z., 2002. White-tailed deer meat and marrow return rates and their application to eastern woodlands archaeology. Am. Antiq. 67, 745-759.

Manzano, A., 2015. Les amphibiens et les reptiles des sites du Pléistocène moyen et supérieur du pourtour méditérranéen (Caune de l'Arago, grotte du Lazaret, Baume Moula-Guercy). Etude d'herpétofaunes et reconstitutions paléoclimatiques et paléoenvironnementales.

Markova, A., Puzachenko, A., 2018. Preliminary analysis of European small mammal faunas of the eemian interglacial: species composition and species diversity at a regional scale. Quaternary 1, 9.

Marlar, R.A., Leonard, B.L., Billman, B.R., Lambert, P.M., Marlar, J.E., 2000. Biochemical evidence of cannibalism at a prehistoric Puebloan site in southwestern Colorado. Nature 407, 74-78.

Marquet, J.-C., 1989. Paléoenvironnement et chronologie des sites du domaine atlantique français d'âge Pléistocène moyen et supérieur d'après l'étude des rongeurs, Dijon.

McPherron, S.P., Dibble, H.L., Chiotti, L., Chase, P., Debénath, A., Farrand, W.R., 2012. Processus de formation des sites et concept du Tayacien: l'exemple de Fontéchevade (Charente, France). L'Anthropologie 116, 321-347.

Moles, V., Boutié, P., 2009. Contribution to the definition of middle paleolithic micro-production. The lithic assemblage from ramandils cave (port-La nouvelle, aude, France). L'Anthropologie 113, 356-380.

Morin, E., Meier, J., El Guennouni, K., Moigne, A.-M., Lebreton, L., Rusch, L., Valensi, P., Conolly, J., Cochard, D., 2019. New evidence of broader diets for archaic $<\mathrm{em}>\mathrm{Homo}</ \mathrm{em}>$ populations in the northwestern Mediterranean. Sci. Adv. 5, eaav9106.

Mourer, C., Ballesio, R., Beden, M., Bouchud, J., Chaline, J., David, L., Guérin, C., Hugueney, M., Jammot, D., Mein, P., 1975. In: Conclusions générales sur les faunes de l'Aven 1 des Abîmes de la Fage à Noailles (Corrèze), 13. Publications du musée des Confluences, pp. 123-129.

Musil, R., 2010. The environment of the middle palaeolithic sites in central and eastern Europe. Acta Universitatis Wratislaviensis, Studia Archaeologica 41. 121-179-121-179.

Neruda, P., 2012. Impact of raw materials on the interpretation of Middle Palaeolithic assemblages. Anthropologie et Préhistorie 50, 345-360.

Neruda, P., Nerudová, Z., 2010. Moravský Krumlov IV-a new multilayer palaeolithic site in moravia. Archaol. Korresp. 40, 155-174. 
Nicholson, C.M., 2017. Eemian paleoclimate zones and Neanderthal landscape-use: a GIS model of settlement patterning during the last interglacial. Quat. Int. 438, 144-157.

Pottier, G., Vacher, J.-P., Savine, N., 2006. Interrogations sur l'existence contemporaine de la Couleuvre de Montpellier Malpolon monspessulanus (Hermann, 1804)(Reptilia, Colubridae) en région MidiPyrénées (France). Bull. Soc. Herp. Fr 120, 33-56.

Richter, J., 2005. Hasty foragers: the crimea island and Europe during the last interglacial. In: Chabai, V., Richter, J., Uthmeier, T. (Eds.), Kabazi II: Last Interglacial Occupation, Environment \& Subsistence. University of Cologne, Cologne, pp. 275-285.

Richter, J., 2008. Neanderthals in their landscape. In: Demars, B., Otte, M. (Eds.), Neanderthals in Europe. Proceedings of the International Conference. ATVATVCA, Tongeren, pp. 17-32.

Richter, J., 2016. Leave at the height of the party: a critical review of the Middle Paleolithic in Western Central Europe from its beginnings to its rapid decline. Quat. Int. 411, 107-128.

Rios-Garaizar, J., Maidagan, D.G., Gómez-Olivencia, A., Avilés, E.I., 2013. Archaeological research in arlanpe cave (Lemoa, biscay). La cueva de Arlanpe (Lemoa) 5.

Rivals, F., Moncel, M.-H., Patou-Mathis, M., 2009. Seasonality and intra-site variation of Neanderthal occupations in the Middle Palaeolithic locality of Payre (Ardèche, France) using dental wear analyses. J. Archaeol. Sci. 36, 1070-1078.

Saladié, P., Rodríguez-Hidalgo, A., 2017. Archaeological evidence for cannibalism in prehistoric western Europe: from Homo antecessor to the bronze age. J. Archaeol. Method Theory 24, 1034-1071.

Sier, M.J., Parés, J.M., Antoine, P., Locht, J.-L., Dekkers, M.J., Limondin-Lozouet, N., Roebroeks, W., 2015. Evidence for the blake event recorded at the eemian archaeological site of Caours, France. Quat. Int. 357, 149-157.

Slimak, L., 2004. La grotte de Néron à Soyons (Ardèche), 26ème Congrès préhistorique de France“ Congrès du Centenaire", Société préhistorique française. pp. 165-175.

Slimak, L., Lewis, J.E., Crégut-Bonnoure, E., Metz, L., Ollivier, V., André, P., Chrzavzez, J., Giraud, Y., Jeannet, M., Magnin, F., 2010. Le Grand Abri aux Puces, a Mousterian site from the Last Interglacial: paleogeography, paleoenvironment, and new excavation results. J. Archaeol. Sci. 37, 2747-2761.

Sørensen, B., 2011. Demography and the extinction of european Neanderthals. J. Anthropol. Archaeol. $30,17-29$.

Speelers, B., 2000. The relevance of the Eemian for the study of Palaeolithic occupation of Europe. Neth. J. Geosci. 7, 283-290.

Stoneking, M., 2003. Widespread prehistoric human cannibalism: easier to swallow? Trends Ecol. Evol. $18,489-490$. 
Swinnen, C., Locht, J.-L., Antoine, P., 1996. Le gisment mousterian D’auteuil (Oise). Bull. Soc. Prehist. Fr. 93, 173-181.

Tuffreau, A., Révillion, S., Somme, J., Aitken, M., Huxtable, J., LEROI-GOURHAN, A., 1985. Le gisement paléolithique moyen de Seclin (Nord, France). Archaol. Korresp. 15, 131-138.

Valensi, P., 2000. The archaeozoology of lazaret cave (nice, France). Int. J. Osteoarchaeol. 10, 357-367.

Valensi, P., Crégut-Bonnoure, E., Defleur, A., 2012. Archaeozoological data from the Mousterian level from Moula-Guercy (Ardèche, France) bearing cannibalised Neanderthal remains. Quat. Int. 252, 4855.

van Kolfschoten, T., 2002. The Eemian mammal fauna of the northwestern and central European continent. In: Tuffreau, A., Roebroeks, W. (Eds.), Le Dernier Interglaciaire et les occupations humaines du Pale'olithique moyen. CERP, Lille, pp. 21-30.

Vanmonfort, B., Vermeersch, P.M., Groenednijk, A.J., Meijs, E.P.M., De Warrimont, J.P., Gullentops, F., 1998. The middle palaeolithic site of hezerwater at veldwezelt, Belgian limburg. Notae Prahistoricae 18, 5-11.

Verleijsdonk, B., 2018. Early Hominin Activity in Waziers. Reconstructing the Environment of the Somme Valley, France during the Eemian Interglacial.

Vilaca, A., 2000. Relations between funerary cannibalism and warfare cannibalism: the question of predation. Ethnos 65, 83-106.

Villa, P., 1992. Cannibalism in prehistoric Europe. Evol. Anthropol. Issues News Rev. 1, 93-104.

Villa, P., Soto, E., Pérez-González, A., Mora, R., 2001. Taphonomy at ambrona: new perspectives. In: Cavarretta, G., Gioia, P., Mussi, M., Palombo, M.R. (Eds.), Proceedings of the First International Congress, the World of Elephants. Consiglio Nazionale delle Ricerche, Rome, pp. 617-619.

Walker, M., Gibert, J., Sánchez, F., Lombardi, A., SERRANO, J., Eastham, A., Ribot, F., Arribas, A., Sánchez-Cabeza, J., GARCÍA-ORELLANA, J., 1998. Two SE Spanish middle palaeolithic sites with Neanderthal remains: sima de las Palomas del Cabezo Gordo and Cueva Negra del Estrecho del Río Quípar (Murcia province). Internet Archaeol. 5.

Weber, T., Litt, T., Schäfer, D., 1996. Neue Untersuchungen zum älteren paläolithikum in mitteldeutschland. Terra and Prehistoria-Beiträge zur Ur-und Fruhgeschichte Mitteleuropas 9, 13-19.

Weißmüller, W., 1995. Sesselfelsgrotte II, Die Silexartefakte der Unteren Schichten der Sesselfelsgrotte. Ein Beitrag zum Problem des Moustérien. Quartär-Bibliothek 6.

Wenzel, S., 1998. Die Funde aus dem Travertin von Stuttgart-Untertürkheim und die Archäologie der letzten Warmzeit in Mitteleuropa, Habelt. 
Vogt, C. 1871. Anthropophagie et sacrifices humains. Congrès International d'anthropologie et d'archéologie préhistorique,( Sesession) Bologne : 295-328.Sonier de Lubac, J., 1873. L'homme au premier age des cavernes.

Epoque du Moustiers, Revue de France. 1873, 841-562.

Wenzel, S., 2007. Neanderthal presence and behaviour in central and northwestern Europe during MIS5e. In: Sirocko, F., Claussen, M., Sanches Goni, M.F., T, L. (Eds.), The Climate of Past Interglacials. Oxford University Press, Oxford, pp. 173-193.

White, T.D., 2001. Once were CANNIBALS. Sci. Am. 285, 58-65.

Willmes, M., Grün, R., Douka, K., Michel, V., Armstrong, R.A., Benson, A., Crégut-Bonnoure, E., Desclaux, E., Fang, F., Kinsley, L., Saos, T., Defleur, A.R., 2016. A comprehensive chronology of the Neanderthal site Moula-Guercy, Ardèche, France. J. Archaeol. Sci.: Report 9, 309-319.

Yustos, M., de los Terreros, J.Y.S., 2015. Cannibalism in the neanderthal world: an exhaustive revision. J. Taphonomy 13, 33-52.

Łanczont, M., Fedorowicz, S., Kusiak, S., Boguckij, A., Sytnyk, O., 2009. TL age of loess deposits in the yezupil I palaeolithic site on the upper dniester river (Ukraine). Geologija 51, 86-96.

\section{Highlights}

- We find that there is poor evidence for nutritional cannibalism at the site of Baume Moula-Guercy.

- The number of Eemian-aged sites in under-reported.

- A lack of sufficient evidence of environmental stress that would warrant nutritional cannibalism.

- Taphonomic evidence on does not strictly support the argument for nutritional cannibalism. 